\title{
Non-Interest Income and Financial Performance of Selected Deposit Money Banks in Nigeria
}

\author{
Emmanuel Uniamikogbo, Rhema University, Aba, Nigeria \\ Emma I. Okoye, Nnamdi Azikiwe University, Awka, Nigeria \\ Akonye Chinazu, Nnamdi Azikiwe University, Awka, Nigeria
}

\begin{abstract}
This study examined the effect of e-banking income, fee income, and firm size on market value added of Deposit Money Banks in Nigeria. The eight banks categorised by Central Bank of Nigeria in 2014 to be Domestic Systematically Important banks were selected using the purposive sampling technique. Data collected from the annual reports and accounts and the Nigerian Stock Exchange website respectively for a period of 11 years (2008-2018) was used. The descriptive statistics and econometric analysis were employed using the Panel Data Analysis method. Findings from the study revealed that e-banking income and fee income each has a significant positive effect on market value added of DMBs in Nigeria. The study recommends that banks in Nigeria should further develop its internet and other electronic platforms that can improve its income from e-banking operations since e-banking income is shown to be a strong and emerging component that boosts banks' performance. Larger and investment-oriented banks should focus on increasing their share of interest income to become more stable.
\end{abstract}

\section{KEYWORDS}

Banking Sector, E-Banking, Fee, Firm Size, Market Value Added, Noninterest Income

\section{INTRODUCTION}

Banks are very important organisations which aid in the execution of socio-economic activities undertaken by individuals, business organisations and the government. They serve primarily as a media which bridge the gap between surplus and deficit units in an economy (Damankah, AnkuTsede, \& Amankwaa, 2014). This fundamental function of banks generates interest income which has over the years been the major source of revenue, since loans form a greater portion of the total revenue-generating assets of banks prior to evolution of digital banking. These assets generate huge interest income for banks which to a large extent determines their financial performance (Mabvure, Gwangwava, Faitira, Mutibvu, \& Kamoyo, 2012). 
Basically, financial flows of Deposit Money Banks (DMBs) are from the intermediation process (for example, interest paid on deposits (interest expense), interest received from loans and securities (interest income), and the resulting net interest margins. Banks promote economic growth primarily by mediating between surplus economic units and deficit economic units. In the process, they facilitate capital formation and lubricate the process of production. This intermediation function is important because, in the absence of banks, savings would have been fragmented in small pockets, but by pooling together such savings banks are able to attain economies of scale with beneficial effects for their credit customers (Nzotta, 2004).

Banks exist because they mitigate a lot of problems that otherwise would have prevented liquidity from flowing directly from agents with excess liquidity (depositors) to agents in need of liquidity (borrowers). These problems arise because of information asymmetries, contracting costs, and scale mismatches between liquidity suppliers and liquidity demanders. Deposit Money Banks' therefore, are seen as solution to these problems by virtue of their intermediating role because they have a comparative advantage at gathering information on borrowers' creditworthiness; better able to monitor borrowers than individual lenders; provide increased liquidity by pooling funds from many households, businesses and by issuing demandable deposits in exchange for these funds; and also diversify away idiosyncratic credit risk by holding portfolios of multiple loans (DeYoung \& Rice, 2004). The relevance of the banking sector is justified by the fact that they not only provide the intermediation used in pooling funds from savers but at the same time redirects them to investors. It also provides the payment system that facilitates trade and exchange as well as a platform for the working out of the monetary policies which provides macroeconomic stability for all economic agents (Saunders \& Walter, 2005).

For banks to perform efficiently and discharge the said core functions, it is imperative that the banks are viable and healthy and that the entire industry is stable and sound. It is against this background that the industry globally is heavily regulated, and most times either proactively or in response to certain industry inefficiencies, embarks on reforms to reposition the industry in order to meet desired objectives (Ebong, 2006). Also, in view of enhancing the overwhelming role of the financial sector and save the banking industry from imminent collapse, the Central Bank of Nigeria (CBN) continually reviews the CBN's prudential guidelines which must be complied with by DMBs in their operations to avoid failures and enhance maximum profitability, liquidity and solvency in the banks' lending activities (Olokoyo, 2011).

Conversely, the global financial crisis of 2008, the Nigerian Banking Sector reforms of 2004, the advent of Treasury Single Account (TSA) which deprives banks access to government funds, the introduction of Islamic Banking which does not charge any interest on loans, high incidences of nonperforming loans occasioned by increased defaults in repayment of loans and advances resulting in impairments or write-offs from banks earnings, increased competition, technological advancement, financial market integration, country's specific regulatory and legislative innovation, among others had posed untold hardships on banks' income hence, reducing the amount of income available from traditional activities of banks in Nigeria. These factors which created pressure on traditional banking activities have made banks to refocus and shift their revenue-mix by diversifying from its interest based activities to non-interest based activities to boost and sustain their revenue base and financial position as financial intermediaries (Dong, 2012) in order to sustain their financial performance and remain in business. Noninterest income services are of continuous development, but whether noninterest income can help enhance DMBs' financial performance has remain contentious.

Prior studies have been conducted in this area of research by scholars in advanced and developing economies like United Kingdom, United States, Ghana, China, Kenya, Bangladesh, Uganda, etc. with none considering the Nigerian environment. However, given the conflicting views of these scholars resulting in inconclusive and lack of uniformity in their submissions, this study believes additional evidence would be needed to address whether noninterest income affects the financial performance of DMBs in Nigeria. 
This paper is structured into five sections. Following the introduction is section two which discusses the literature review and hypotheses development under three sub-heads as: conceptual review, theoretical review and review of empirical studies. Section three harps on the methodology. This is followed by section four which focuses on estimation results and discussion of findings, and finally, section five presents the conclusion and recommendations.

\section{LITERATURE REVIEW AND HYPOTHESES DEVELOPMENT}

\subsection{Concept of Noninterest Income}

Noninterest income is basically income earned from sources other than returns on bank advances. Noninterest income is the part of a bank's revenue that is not generated by its interest-bearing activities. They are revenues that banks earn from areas outside their lending operations or any income that banks earn from activities other than their core intermediation business or from investment in other business portfolios (Khrawish, 2011). Noninterest income is generally derived from commission and fee activities, e-channels activities (such as Automated Teller Machine, Point of Sale, Mobile banking, Internet banking, and so on) and trading activities. They are usually fee-generating activities which range from underwriting activities, cash management and custodial services to derivative arrangements. Non-interest income also includes activities such as income from trading and securitization, investment banking and advisory fees, brokerage commissions, venture capital, fiduciary income, and gains on non-hedging derivatives. These activities are different from the traditional deposit taking and lending functions of banks. In these activities, banks are competing with other capital market intermediaries such as hedge funds, mutual funds, investment banks, insurance companies and private equity funds which are important for financial stability (Brunnermeier, Dong \& Palia, 2012).

The components of non-interest income of banks in Nigeria include monthly account service charges, deposit and transaction fees, commissions, dividends and trading profits on securities, foreign exchange net gains, insufficient funds fees, annual fees, inactivity fees, cheque and deposit slip fees, and other operating income. Banks charge fees on some activities that provide non-interest income as a way of generating revenue and ensuring liquidity in the event of increased default rates (Kaufman \& Mote, 1994). As part of total bank earnings, noninterest income is gaining prominence in recent times particularly in the US and Europe, as competition intensifies in the traditional banking business of deposit mobilization and loan advances (De Young \& Rice, 2004). Noninterest income is what banks are striving for in recent years because of the vigorous competition among DMBs due to increasingly open market and tough regulations from the Central Bank of these various countries (Sun, Wu, Zhu \& Stephenson, 2017). Banks therefore, are increasingly depending on noninterest income for their survival and success in generating revenues and profit (Bian, Wang \& Sun, 2015).

According to Ritter and Udell (1996), this source of revenue has become more important in recent times as banks have shifted from the traditional interest income to more of non-traditional income known as noninterest income or fee income. This shift towards noninterest income has increased banks' revenue as noninterest income is one of the significant factors influencing banks' profitability (Oniang'o, 2015). This income source has great growth significance on the total income and financial performance of banks.

\subsection{Electronic Banking}

According to the "Report of Technical Committee on e-banking" (CBN, 2003), e-banking is "a means whereby banking businesses are transacted using automated processes and electronic devices such as personal computers, telephones, facsimile, internet, card payments and other electronic channels." Electronic banking involves the delivery of financial services outside conventional bank branches, using technologies such as card-reading Point-of-Sale (POS) terminals, Automated Teller Machine (ATM), Mobile Phones, Internet, and so on to transmit transaction details (Onwudiwe, 2017). 
Information and communication technologies trends in the banking industry has made DMBs to introduce mobile applications and Smart ATMs to replace human tellers, internet banking to eradicate the problem of geographical distance as well as the emerging digital peer-to-peer banking. Among other benefits, e-banking increases banks revenue, customers need not visit the bank's branch and banks have the opportunity of enhancing their customer base thereby experience improved profits (Okibo \& Wario, 2014).

According to International Monetary Fund (2010), financial innovation has resulted to the emergence of vital services that evaluate, allocate and monitor the use of capital, while enhancing transactions and risk management. These improvements have resulted to significant changes in the demographics of the operation of commercial banks all over the world. Analysis of the audited 2018 annual reports of 11 Deposit Money Banks in Nigeria showed their revenue earned from electronic transactions grew from N86.72bn in 2017 to N124.5bn in 2018, representing a 43 percent growth rate (Financial Punch, 2019).

\subsection{Electronic Banking Channels}

It is important to note that noninterest income channels entirely comprise technologically based financial innovations (Alubisia, Githii, \& Mwangi, 2018). As such, technologically based financial innovation is at the heart of commercial banks' business as they seek to profit from noninterest income (Beck et al., 2016). There are several technology based financial innovations that have been developed for ease of doing business in the banking sector and some of which include ATMs, credit and debit cards, online and mobile banking applications as well as funds transfer systems (FTS) such as real time gross settlement (RTGS) and electronic funds transfers (EFT). These electronic banking channels are briefly explained below.

\subsubsection{Automated Teller Machine (ATM)}

An ATM is basically a computer terminal that comprises of a cash vault and a record keeping system capable of holding records of account information. An individual who wants to utilize ATM services should have a credit or debit card that has a chip with their account information as well as their Personal Identification Number (PIN) that will communicate with the ATM computer and allow the transaction (Shaikh \& Karjaluoto, 2015). The ATM offers a number of services to its users including the ability to withdraw, deposit, buy airtime, pay utility bills or transfer cash from one geographical location to another electronically. They are widespread, and need not be physically located near banking institutions.

\subsubsection{Online Banking (OB)}

An online banking is a service provided by a commercial bank that allows customers to conduct financial transactions as if they were physically present in a banking hall while in reality they are using their mobile phones (Shaikh \& Karjaluoto, 2015). It entails accessing banking services via the internet which is also referred to as internet banking (Yee-Loong, Chong, Ooi, Lin \& Tan, 2010). This means, banking services (such as accessing accounts, checking balances, point of sale purchases and transfer of large amounts of money via Electronic Funds Transfers (EFT) that would otherwise be only available in a banking hall are accessible remotely. It uses software in the form of an app that is provided by the financial institution to the customer for the sole purpose of transacting.

\section{FUND TRANSFER SYSTEM (FTS)}

Fund Transfer System (FTS) comprises of systems that facilitate the transfer of large amounts of money from one institution to another (Worku, 2010) and includes Real Time Gross Settlement (RTGS) and Electronic Funds Transfers (EFT). RTGS enables the movement of funds from one banking institution 
to another in such a way that the settlement is in real time, that is transactions are not subjected to time, and take place instantly. In essence, settlements are completed as soon as they are processed on a one to one basis, eliminating the need for netting with any other transaction at the bank. This has revolutionized transactions that are of high-value and require immediate settlement. On the other hand, EFT is a form of electronic funds transfer that also handles high-value transactions. However, settlements done through this system are not real time but also rely on a network to function (Jack, Suri \& Townsend, 2010). Based on the above, the first hypothesis of this study is presumed as follows:

$\mathbf{H}_{\mathbf{0}}$ : Electronic banking income has no significant effect on market value added of Deposit Money Banks in Nigeria.

\subsection{Fee Income}

Fee income is the revenue taken by banks from account-related charges to customers. Charges that generate fee income include non-sufficient funds fees, late fees, over-the-limit fees, wire transfer fees, monthly or annual service charges, account research fees and many more. Credit unions, banks and credit card companies are types of financial institutions that earn fee income. Financial institutions earn a significant portion of their income from fees which also forms part of noninterest income.

Before the deregulation of the mid-1980s which offered banks more opportunities to sell non-traditional fee-based services, non-interest income had already accounted for nearly a quarter of all operating income generated by commercial banks (DeYoung \& Rice, 2004). The dramatic increase in noninterest income at U.S. banking institutions over the last two decades reflects not only diversification of banks into non-traditional activities but also a shift on how banks earn money from their traditional banking activities. During this period, deregulation opened the door for commercial banks to earn fee income from investment banking, merchant banking, insurance agency, securities brokerage, and other non-traditional financial services.

Noninterest fee income actually took off with the Gramm-Leach-Bliley (GLB) Act of 1999, also known as the Financial Services Modernization Act of 1999 was enacted November 12, 1999 as an act of the 106th United States Congress (1999-2001), which created a financial holding company (FHC) framework allowing common ownership of banking and non-banking activities. The GLB Act was the catalyst eliminating the vaunted Glass-Steagall Act of 1933, which prohibited the mixing of commercial banking with other financial services activity, such as investment banking services, securities services, and insurance services. Williams (2016) argues that the increase in fee income is not only due to the decrease in net interest margins but also owing to the change of banking business models. On the contrary, the Scope of Banking Activities \& Ancillary Matter Act, 2010 of Nigeria introduced a narrower banking services model restricting banks from performing non-banking activities such as insurance and portfolio management businesses in Nigeria despite the fact that increased reliance on fee-based income may increase banks' earnings streams. It is on this basis that our second hypothesis is stated as follows:

$\mathbf{H}_{\mathbf{0} 2}$ : Fee income has no significant effect on market value added of Deposit Money Banks in Nigeria.

\subsection{Firm Size}

The size of the firm is one of the decisive factors in the achievement of efficiency in its operations. These days, large-scale production is considered to bring most economic results by way of lower costs and higher returns. Therefore, there has been a tendency towards increase in the size of the industrial units in order to organise mass production and bulk sales in diversified markets. Larger firms may also enjoy economies of scale in monitoring top management (Hummelberg, Hubband \& Palia, 1999; Penrose, 1959). Larger firms, according to Shepherd (1970) may also be able to leverage their market power. Zeitun and Tian (2007) also posit that firm size has a positive impact on firms' performance 
as large firms have low bankruptcy costs. Also, the effect of this variable on efficiency is likely to be positive as larger firms are expected to use better technology, be more diversified and better managed.

The generally accepted norm in modern economic analysis is that as the firm's business goes on expanding, the cost per unit would be declining. Therefore, all firms tend to expand their scale of operations in order to spread their costs over larger output. However, there is a limit to which they can grow without adverse effect on its profitability. Growth beyond that limit may give decreasing return per unit of investment due to managerial and financial strains. Therefore, a negative effect may be observed in situations where there is loss of control resulting from inefficient hierarchical structures in the management of the company (Williamson, 1967). Larger firms also tend to incur larger monitoring costs which may offset the benefits of economies of scale stated above.

Firm size is measured by the natural log of the firm's total asset. According to CBN (2014), bank size (BSZ) is measured by the total asset of the bank. In this study therefore, we would expect a positive relationship between firm's size and financial performance of deposit money banks in Nigeria. Thus, our third hypothesis is stated as follows:

$\mathbf{H}_{\mathbf{0} 3}$ : Firm size has no significant effect on market value added of Deposit Money Banks in Nigeria.

\subsection{Market Value Added (MVA)}

Market Value Added (MVA) is defined as the difference between the company's market value (Debt and Equity) and the economic capital invested in the business (Young \& O'Byrne, 2000). The economic capital or invested capital (IC) represents the amount that has been placed in the company and consists mainly of non-current assets plus net-working capital. MVA is an external value-based performance measure, which is considered to be the best indicator of shareholders' value creation (Khan, Chouhan, Chandra, \& Goswami, 2012) unlike the economic value added that is deemed to measure performance internally (Kiwan, 2010). MVA has presented a new shareholders' value measure (Stewart, 1991) which describes the market based value added over the book value of invested capital. In the study conducted by (Stewart, 1991; Alipour \& Pejman, 2015), MVA was used as a dependent variable and displays the value-added created for the shareholders and investors.

Although, the market value added is calculated at a certain point in time, it can be calculated for several periods for the purpose of determining the difference or change in value added and to know whether there has been improvement or reversal (Bognarova, 2017). A positive MVA indicates that the value and investment created by the management is more than the capital supplied by the investors while a negative market value indicates a decline or decrease in the company's value (Wibowo \& Berasategui, 2008). Where an enterprise has made a return equal to the cost of its capital, the market value added in this case would be zero, but if the enterprise could achieve revenues higher than the cost of the invested capital, the market value added would be positive. The market value added represents the amount of wealth generated from the capital and reflects the market assessment of the effectiveness of the enterprise's management in the use and control of available resources and the competitive position in the market (Jadoo, 2007). In this context, the MVA is the difference between equity market value and equity book value (Invested Capital) (Panigrahi, 2017) as shown below:

MVA = Equity Market Value - Invested Capital

where:

Equity Market Value $=$ Number of Outstanding Shares X Market Price per Share

Invested Capital $=$ Non-Current Asset + Working Capital

Working Capital $=$ Current Assets - Current Liabilities 


\section{REVIEW OF THEORY}

\subsection{Modern Portfolio Theory}

The Modern Portfolio Theory (MPT) is an investment theory developed by Markowitz (1952). MPT is one of the most important and influential economic theories dealing with finance and investment management. The idea behind this theory is that risk-averse investors could come up with investment portfolios to optimize or maximise expected returns based on a given level of market risk, emphasizing that risk is an inherent part of higher reward. The MPT shows that specific risk can be removed through diversification. The two main concepts in "Modern Portfolio Theory" are that: (i). an investor's goal is to maximize return for any level of risk, and (ii). Risk can be reduced by creating a diversified portfolio of unrelated assets. Technically speaking, the MPT comprised of Markowitz' "Portfolio Selection Theory", first introduced in 1952, and William Sharpe's contributions to the theory of financial asset price formation which was introduced in 1964, which came to be known as the Capital Asset Pricing Model ("CAPM") (Veneeya, 2006).

Essentially, MPT is an investment framework for the selection and diversification of investment portfolios based on the maximisation of expected returns of the portfolios and the simultaneous minimisation of investment risk (Fabozzi, Gupta, \& Markowitz, 2002). The fundamentals of MPT are asset's risk-return on the overall investment portfolio. The view of Markowitz (1952) is that an asset's risk and return should not be assessed by itself, but by how it contributes to a portfolio's overall risk and return. MPT, however, shows that a mixture of diverse assets will significantly reduce the overall risk of a portfolio. However, risk has to be seen as a cumulative factor for the portfolio as a whole and not as a simple addition of single risk. MPT assumes that investors are risk-averse, meaning that given two portfolios that offer the same expected return, investors will prefer the less risky one. Conversely, an investor who wants higher expected returns must accept more risk. The concept of "risk and return trade-off" as relates to Markowitz's basic principle states that the riskier the investment, the greater the required potential return. Thus, generally speaking, investors will keep a risky security only if the expected return is sufficiently high enough to compensate them for assuming the risk (Ross, Westerfield, \& Jaffe, 2002). He therefore states that investors should be aware of the relationship between risk and return of a financial asset.

Overall, the risk component of MPT can be measured, using various mathematical formulations, and reduced via the concept of diversification which aims to properly select a weighted collection of investment assets that together exhibit lower risk factors than investment in any individual asset or singular asset class. Diversification is, in fact, the core concept of MPT and directly relies on the conventional wisdom of "never putting all your eggs in one basket" (McClure, 2010; Fabozzi, et al., 2002).

The Modern Portfolio Theory (MPT) is adopted as the most appropriate economic theory on finance and investment management in this study because literature on banks' diversification of products and services essentially from interest based activity towards noninterest based activity and its characteristics revolve principally around the modern portfolio theory. This theory develops a framework where, any anticipated return has different expected outcomes, thus, guides the investor on ruling on investment portfolios. The acceptance of MPT model to explain the risk-return trade-off is due to a number of factors such as complete information available in the markets, investing in portfolio stocks rather than individuals, and diversified portfolios held by investors over short observation periods. Furthermore, diversification and investment portfolios are the core concept of MPT which form the basis of this study. Moreso, other economic theories on finance and investment management like capital assets pricing model (CAPM) and Arbitrage Pricing Theory (APT) were upshots and iterations of MPT of Markowitz (1952). 


\subsection{Review of Empirical Studies}

Gueyié, Guidara, and Lai (2019) examined the impact of noninterest income on Canadian banks' risk, performance and capital under the different major regulatory changes made to the Bank Act of Canada using the big six Canadian chartered banks quarterly financial statements and daily stock market data from 1982 to 2018. The banks' quarterly financial statements and daily stock market data were analysed using descriptive statistics and regressions. Their results showed that Canadian banks' expansion into nontraditional activities had slightly decreased their risks and significantly improved their performance from income diversification. Moreover, while adhering to capital adequacy regulation, reshuffling banks' portfolio towards non-traditional activities did not reduce Canadian banks' capital ratio.

Isshaq, Amoah, and Appiah-Gyamerah (2019) examined the determinants of noninterest income and its implications for bank risk-return trade-offs, medium-term profitability and profit variability in Ghana. Specifically, variables considered were Return on Assets, non-interest income to total assets, noninterest income to shareholders equity, net interest margin, return on equity, commissions and fees to total deposits, net interest income to shareholders equity and cost-to-income ratio (interest expense and operating expense to total revenue). Secondary data from the bank-level financial statement and World Development Indicators (WDI) were obtained from the Ghana Bankers Association and the World Bank respectively for the period 1999 to 2015 with 200 observations. The data were analysed using descriptive statistics and regression. They found that cost-efficiency is key to generating and profiting from non-interest income as the volume of loans generated and liquid assets were held by the bank. Their findings also revealed that while large banks may profit from noninterest income but, not necessarily relying on it for their profits, they do not find non-interest income detrimental to bank solvency, perhaps because the nature of non-interest income of the sample banks may not expose bank capital to significant risk of loss.

Andrzejuk (2019) examined the relation between noninterest income and bank's profitability for Liechtenstein banks. The study examines 12 Liechtenstein banks which specialised in private banking and wealth management services for the period 2014 to 2016. Data used in the study were gotten from the published financial statements of the banks. The relationship between profitability, proxied by return on equity (ROE) and return on assets (ROA), and noninterest to interest income ratio was analysed using Pearson correlation coefficient. Results showed a negative correlation between noninterest to interest income ratio and ROA. No relevant correlation was found between non-interest to interest income ratio and ROE.

Okello and Muturi (2018) investigated the influence of non-interest income on financial performance of commercial banks listed on the Nairobi Securities Exchange for 2012 to 2017 periods. The variables used in the study were non-interest income as independent variable and performance as dependent variable. The independent variable which is noninterest income was proxied by bank commission on loans and advances, income from foreign exchange trading, investment income and transaction and account related income while the dependent variable which is performance was proxied by Return on Assets (ROA). The research design employed was a descriptive survey with a sample size of eleven (11) commercial banks listed on the Nairobi Securities Exchange. The study used the secondary data collection method for data generation. The multiple regression analysis was done using SPSS to analyze data collected. The study concluded that there was a positive relationship between non-interest income and financial performance of commercial banks in Nairobi. The study further established that non-interest income influenced $28.5 \%$ of the total variance in commercial banks financial performance.

Huseyin (2018) examined the impact of non-interest income on banks' profitability in Turkey. His sample size consists of 205 countries banks for the period of 1999-2015 using the breaks OLS regression and Bayesian Impulse Response analyses. The study findings showed that for the year 2011, non-interest income rates had positive significant impact on 205 countries banks' return on asset ratios. Moreover, for the period 1999-2013, there was positive and significant relationship between 
high income countries' banks' profits and non-interest income rates. No relationship was found for medium and low income countries. Non-interest income therefore had a positive and significant impact on Turkish banks' profits for all the breaks of January 2003- July 2015.

Sun, Wu, Zhu and Stephenson (2017) investigated the relationship between noninterest income and performance of commercial banks in China using 16 listed Chinese commercial banks for the period 2007 to 2013. The regression analysis technique was employed using a panel threshold model with balanced panel dataset to analyze data generated. The findings showed a nonlinear relationship between noninterest income and performance of commercial banks in China. Also, a general negative correlation exists between the noninterest income ratio and performance of commercial banks.

Al-Tarawneh, Abu-Khalaf, and Al-Assaf (2017) investigated the impact of noninterest income on financial performance of banks in Jordan. They used 16 banks in Jordan during the period 2000 to 2015. Variables used were; Size, Loans, Capital adequacy, Overheads, Noninterest income margin as proxies for independent variables while profitability was used as proxy for dependent variable. Data was collected from each bank's annual reports, financial statements, and information available on the Amman Stock Exchange website. Data collected from these secondary sources were analyzed using descriptive statistics and correlation matrix. Their findings showed that noninterest income has a significant impact on banks performance by increasing the equity capital adequacy which in turn positively affects profitability.

Gichure (2015) investigated the relationship between noninterest income and financial performance of commercial banks in Kenya using 42 commercial banks operating between 2010 and 2014. The data collected from the annual reports and accounts of selected banks was analyzed using SPSS version 20, ANOVA, descriptive and regression analyses. Findings from the study showed that there was a negative relationship between noninterest income and financial performance occasioned by the variability in the ratio of non-interest income and net interest income of banks in Kenya.

\section{METHODOLOGY}

This study adopts the ex-post facto research design with an extensive reliance on secondary data obtained from the corporate annual reports \& accounts of the selected banks listed on the Nigerian Stock Exchange as at $31^{\text {st }}$ December, 2017. The population of this study consists of 16 DMBs listed in the Nigerian Stock Exchange (NSE) as at $31^{\text {st }}$ December 2017, from which a sample of eight (8) banks categorised by the Central Bank of Nigeria to be Domestic Systemically Important Banks (D-SIBs) (CBN, 2014) in the Nigerian banking sector was selected. The purposive sampling technique was adopted in selecting the sample size from the population. The study covered a period of eleven (11) years spanning 2008-2018. The statistical tools employed were the descriptive statistics and econometric analysis. Multiple regression model was employed to capture four (4) variables comprising dependent and independent variables. The specified variables are market value added, electronic banking income, fee income, and firm size. Data generated from the selected banks' corporate annual reports \& accounts and NSE website were analysed using tables and regression.

The model is expressed functionally as:

Market value added $=f($ Electronic banking income, Fee income, Firm size $)$

The econometric model is expressed thus:

$\mathrm{MVA}_{\mathrm{it}}=\beta_{0}+\beta_{1} \mathrm{~EB}_{\mathrm{it}}+\beta_{2} \mathrm{FEE}_{\mathrm{it}}+\beta_{3} \mathrm{FSIZE}_{\mathrm{it}}+\varepsilon_{\mathrm{it}}$

where: 
MVA = Market Value Added

$\mathrm{EB}=$ E-banking Income

$\mathrm{FEE}=$ Fee Income

FSIZE $=$ Firm size

$\mathrm{i}(=1,2,3, \ldots 8)$ is the given deposit money banks

$\mathrm{t}=$ Time dimension of the variant

$\varepsilon=$ error term

$\beta_{0}=$ the intercept coefficient

$\beta_{1}-\beta_{3}=$ the coefficients of the parameter estimate

Also:

$\beta_{1}, \beta_{2}, \beta_{3}<0$

\section{DATA PRESENTATION AND ANALYSIS}

Table 1 presents annualised mean, annualised standard deviation and other summary statistics on the noninterest income and other variables for a sample of banks in Nigeria. The descriptive statistics

Table 1. Descriptive statistics of the data

\begin{tabular}{|c|c|c|c|c|c|c|c|c|}
\hline & Mean & Max. & Min. & $\begin{array}{l}\text { Std. } \\
\text { Dev. }\end{array}$ & Skew. & Kurt. & J-B & Prob. \\
\hline EBSH & 5.76 & 32.86 & 0.72 & 6.16 & 2.21 & 8.24 & 172.71 & 0.000 \\
\hline FEESH & 15.06 & 74.57 & 1.72 & 12.74 & 2.91 & 12.07 & 425.74 & 0.000 \\
\hline MVALR & 11.96 & 22.87 & -18.59 & 34.65 & 4.43 & 23.71 & 1861.36 & 0.000 \\
\hline FSIZE & 14.29 & 16.89 & 11.16 & 0.76 & -0.83 & 7.08 & 71.16 & 0.000 \\
\hline
\end{tabular}

Source: Researchers' computations

shows that average share of e-banking income in total revenues for the banks is 5.76 percent, and that of fees is 15.06 percent. This indicates that more of the noninterest incomes for the banks are from fees and e-banking income and provide relatively lesser revenue contributions in terms of total shares. Table 4.1 also shows that some banks had up to 32.86 percent of total revenues in form of e-banking income. This suggests that individual banks may have varied income proportions with respect to contributions of noninterest income activities. The standard deviations for each of the variables are relatively close to their respective mean values, suggesting that the average revenues shares of each of the income categories appear to be considerably stable across banks in the sample. Apparently, the patterns of noninterest income sourcing by the banks do not change extensively over time or across banks. It appears the leading sources of noninterest income for the different banks are essentially similar as well as the least sources of such income among the banks.

The descriptive statistics thus shows that overall, noninterest income for the selected banks constituted 39.05 percent of total revenue over the period. This shows that for Nigerian banks, revenues from noninterest sources provide significant contributions to overall revenues. This explains the constant focus of the banking sector in terms of increased drive for revenues that are outside of the core interest (or lending-based revenues). It can also be shown that noninterest income of banks may have actually increased considerably over the last few years in Nigeria. Each of the income 
categories for J-B tests are high and passed the significance tests at the 1 percent level. This shows that the datasets are non-normally distributed.

For the performance variables, the summary statistics in Table 4.1 shows that average market value ratio for the banks is however high at 11.96 percent, with a standard deviation value of 34.45 which suggests very high degree of variations in the market value across the banks in the sample. Average size of banks is 14.29 years. The characteristics of the banks shown in the Table suggests that while banks are relatively similar in terms of the relative importance of noninterest revenues, the banks are largely dissimilar in terms of market value performances over the period of the analysis. The relative importance of each of the noninterest income to revenue of the sampled banks is also presented in Figure 1. As was noted earlier, income from fees dominates the noninterest revenue stream for the banks in the sample.

In Table 2, the result of the analyses of noninterest income and other variables on banks' market value is presented. The goodness of fits statistics is also impressive with the adjusted R-squared value

Table 2. Noninterest income and banks' financial performance (dependent variable is market value)

\begin{tabular}{|l|l|l|l|l|l|l|}
\hline \multirow{2}{*}{ Variable } & \multicolumn{3}{c|}{ With Control } & \multicolumn{3}{c|}{ Without Control } \\
\cline { 2 - 7 } & \multicolumn{1}{|c|}{ Coeff. } & \multicolumn{1}{|c|}{ t-Stat. } & \multicolumn{1}{c|}{ Prob. } & \multicolumn{1}{c|}{ Coeff. } & \multicolumn{1}{c|}{ t-Stat. } & Prob. \\
\hline Constant & 256.496 & 4.908 & 0.000 & 8.128 & 0.174 & 0.862 \\
\hline EB & 13.953 & 4.330 & 0.000 & 11.381 & 3.052 & 0.003 \\
\hline FEE & 11.354 & 2.541 & 0.013 & 6.513 & 1.154 & 0.252 \\
\hline FSIZE & -34.271 & -7.446 & 0.000 & & & \\
\hline Adj. R-sq. & 0.646 & & & 0.400 & & \\
\hline F-stat & 23.66 & & & 12.58 & & \\
\hline
\end{tabular}

Source: Researchers' computations

at 0.646 for the full model. The F-statistic value is also high and significant for the equation and indicates a significant relationship between the dependent variable and all the independent variables combined. Again, we focus on the full equation (without controls for bank size) and use the equation without controls as robustness checks. A close look at the individual coefficients of the explanatory variables shows that all the noninterest income variables have significant coefficients at the 5 percent level. This confirms that these incomes of the banks do essentially affect the market performance of the banks in Nigeria.

The significant variables in the results showed that the coefficients of income from e-banking and fees are positive with values 13.953 and 11.354; $\mathrm{t}$-value $=4.330$ and 2.541 and an associated probability of 0.000 and 0.013 , while that of the control variable, firm size (FSIZE) is negative and statistically significant with the coefficient $\left(\beta_{1}\right)$ of -34.271 ; $\mathrm{t}$-value $=-7.446$ and an associated probability of 0.000 . The outcome of the bank size reveals that bigger banks may have lesser market value than smaller banks. The results therefore demonstrate that increasing noninterest income will boost the market value of banks in Nigeria. This direct positive effect also shows how important noninterest income is to banks, not only as a means of increasing revenues, but also to promote bank market values.

The results from the empirical analysis have certain important implications in terms of previous studies and relevance for discussion. In the first place, the results highlight a very critical aspect of noninterest income of banks in Nigeria. It is shown that e-banking activities have income that is highly important in terms of bank performance in Nigeria. First, this component of noninterest income was shown to contribute more than most of the other components in terms of bank revenues. Second, 
this component is a recent aspect of noninterest income for banks in Nigeria. Thus, it is seen that innovative aspects of bank noninterest revenues have greater effect on bank performance more than the traditional aspects of noninterest income like fees. Banks that engage more in modern e-banking activities are more likely to perform better in Nigeria.

Another implication from the study results is that it might be beneficial for retail-oriented banks in Nigeria to increase their share of noninterest income by focusing on e-banking activities and fees. This will enable them to expand revenues and ensure more stability over time, since this allows them to better diversify their income structure and to become more resilient in the financial market. The results from the study are in line with recent findings for the banking sectors of both advanced and less developed economies which indicate substantial benefits from noninterest income for Deposit Money Banks (Köhler, 2015; Senyo, Olivier, \& Musah, 2015; Adedeji \& Adedeji, 2018). However, these findings disagree with the studies outputs conducted by Chien-Chiang, Shil-Jui, and Chi-Hung (2014) and Mndeme (2015) who recorded that e-banking income and fee income reduce banks financial performance.

\section{CONCLUSION AND RECOMMENDATIONS}

\subsection{Conclusion}

The diversity of banking operations in recent times has become a subject of interest to the management of banking companies, regulators, bank customers and other stakeholders. This is because the banking environment has become more competitive, requiring constant innovation in maintaining heights required for sustainability. The role of noninterest income on banks' market value added examined based on evidence from a sample of Nigerian banks showed that certain elements of noninterest banking are important for boosting the market value added of banks. The noninterest income elements found to have contributed significantly and positively to the growth of market value added of deposit money banks as revealed by the results of our analyses were e-banking income and fee income. Thus, diversifying into elements of noninterest activities has helped to promote market value added of DMBs in Nigeria. Therefore, banks are advised to expand their noninterest operations in these directions with a view to boosting their revenue stream as well as further improve their market value added. However, the situation is quite different for firm size which showed a significant negative effect on market value added of banks in Nigeria. This implies that the size of banks negatively impacts on banks' market value added. With larger banks involvement in noninterest income activities at the detriment of interest bearing activities may increase the risk of the banking sector and ultimately reduce the banks overall performance. Larger and more investment-oriented banks should focus on increasing their share of interest income to become more stable and contribute more appropriately to the economy. Thus, banks should maintain an effective balance between the drive for increasing noninterest income and focusing on the core intermediary functions to boost the market value added and stability of deposit money banks in Nigeria.

\subsection{Recommendations}

Based on the findings, the following recommendations were suggested:

1. Banks should further develop its internet and other electronic platforms that can improve its income from e-banking since e-banking income is shown to be a strong and emerging component of noninterest income that boosts banks' market value added;

2. Banks should be more mindful of the means of acquiring noninterest income if the goal is to promote the banks market value added since it depends on the activities used to generate noninterest income for the bank;

3. Larger and more investment-oriented banks should focus on increasing their share of interest income to become more stable and contribute more appropriately to the economy. 


\section{REFERENCES}

Adedeji, A. O., \& Adedeji, O. A. (2018). Effect of noninterest income on banks' profitability in Nigeria. Journal of Economics. Management and Trade, 21(9), 1-10.

Al-Tarawneh, A., Abu Khalaf, B. K., \& Al Assaf, G. (2017). Noninterest income and financial performance at Jordanian banks. International Journal of Financial Research, 8(1), 166-171. doi:10.5430/ijfr.v8n1p166

Alipour, M., \& Pejman, M. E. (2015). The impact of performance measures, leverage and efficiency on market value added: Evidence from Iran. Global Economics and Management Review, 20(1), 6-14. doi:10.1016/j. gemrev.2015.04.001

Alubisia, L. B., Githii, W., \& Mwangi, M. (2018). Effect of technology based financial innovations on noninterest income of commercial banks in Kenya. European Scientific Journal, 14(7), 337-349. doi:10.19044/ esj.2018.v14n7p337

Andrzejuk, K. (2019). Non-interest income and profitability in private banking. Evidence from Liechtenstein. International Journal of Synergy and Research, 175-182.

ATM Benchmarking Study 2018 and Industry Report. (2018). Retrieved 11 September 2018 fromhttps://www. accenture.com/_acnmedia/PDF-10/Accenture-BankingATMBenchmarking2016.pdf

Baek, S., Youn Cha, S., \& Lee, N. (2015). The effect of the diversification in Korean banks: The impact on profit and risk. Journal of Accounting and Finance, 15(2), 51-69.

Bian, W., Wang, X., \& Sun, Q. (2015). Non-interest Income, Profit, and Risk Efficiencies: Evidence from Commercial Banks in China. Asia-Pacific Journal of Financial Studies, 44(5), 762-782. doi:10.1111/ajfs.12112

Bognárová, K. (2017). Analysis of the relationship between economic value added and market value added. Challenges of the knowledge society. Finance and Accounting, 7, 793-796.

Brunnermeier, M. K., Dong, G. N., \& Palia, D. (2012). Banks' non-interest income and systemic risk. AFA 2012 Chicago Meetings Paper.

Central Bank of Nigeria. (2014). Framework for the regulation and supervision of domestic systemically important banks (SIBs) in Nigeria. Author.

Damankah, S. B., Anku-Tsede, O., \& Amankwaa, A. (2014). Analysis of non-interest income of commercial banks in Ghana. International Journal of Academic Research in Accounting, Finance and Management Sciences, 4(4), 263-271.

DeYoung, R., \& Rice, T. (2004). Non-interest income and financial performance at U.S. Commercial Banks. Financial Review, 39(1), 101-127. doi:10.1111/j.0732-8516.2004.00069.x

Dong, G. (2012). Essays in banking and finance: Securitization, systemic risk and Healthcare reform (Doctoral dissertation). Rutgers University.

Ebong, B. B. (2006). Banking sector reforms: Opportunities and challenges. Union Digest, 10(12), 1-13.

Fabozzi, F., Gupta, F., \& Markowitz, H. (2002). The legacy of modern portfolio theory. Journal of Investing, 11(3), 7-22. doi:10.3905/joi.2002.319510

Gichure, K. S. (2015). The relationship between noninterest income and financial performance of commercial banks in Kenya. A research project submitted in partial fulfillment of the requirements for the award of the degree of master of business administration, school of business. University of Nairobi.

Gueyié, J., Guidara, A., \& Lai, V. (2019). Banks' non-traditional activities under regulatory changes: Impact on risk, performance and capital adequacy. Journal of Applied Econometrics, 1-30.

Hummelberg, C. P., Hubband, R. G., \& Palia, D. (1999). Understanding the determinants of managerial ownership and the link between ownership and preference. Journal of Financial Economics, 53(3), 353-384. doi:10.1016/ S0304-405X(99)00025-2

Huseyin, C. (2018). The impact of non-interest income on banks' profitabilities. Journal of Advanced Management Science, 6(3), 161-164. 
International Monetary Fund. (2010). Financial innovation and risk, the role of information. IMF Working Papers. International Journal of Financial Studies, 6(40), 1-25.

Isshaq, Z., Amoah, B., \& Appiah-Gyamerah, I. (2019). Non-interest income, risk and bank performance. Global Business Review, 20(3), 595-612. doi:10.1177/0972150919837061

Jack, W., Suri, T., \& Townsend, R. M. (2010). Monetary theory and electronic money: Reflections on the Kenyan experience. Research on Financial and Economic Issues, 5(10), 245-357.

Jado, S. K. (2007). Analytical study of the effectiveness of the application of value-based management to maximize the value of equity in economic units, a field study. Scientific Journal of Economics and Commerce, 1(2).

Kaufman, G. G., \& Mote, L. R. (1994). Is banking a declining industry? A historical perspective. Federal Reserve Bank of Chicago Economic Perspectives, 18(1), 2-21.

Khan, S., Chouhan, V., Chandra, B., \& Goswami, S. (2012). Measurement of value creation vis- a-vis EVA: Analysis of select BSE companies. Pacific Business Review International, 5(3), 114-131.

Khrawish, H. A. (2011). Determinants of commercial banks performance: Evidence from Jordan. International Research Journal of Finance and Economics, 5(5), 19-45.

Kiwan, R. (2010). The effect of managers' entry structure on economic value added in Egyptian establishments, applied study. Journal of Commercial Researches, 32(1).

Köhler, M. (2015). Which banks are more risky? The impact of business models on bank stability. Journal of Financial Stability, 16, 195-212. doi:10.1016/j.jfs.2014.02.005

Mabvure, T. J., Gwangwava, E., Faitira, M., Mutibvu, C., \& Kamoyo, M. (2012). Non- performing loans in Commercial Banks: A case of CBZ Bank Limited in Zimbabwe. Interdisciplinary Journal of Contemporary Research in Business, 4(7), 1-22.

Markowitz, H. (1952). Portfolio Selection. The Journal of Finance, 7(1), 77-91.

McClure, B. (2010). Modern portfolio theory: Why it's still hip. Investopedia. Retrieved on 16/11/2018 from https://www.investopedia.com/articles/06/MPT.asp\#axzz1g3JQY7nY

Nzotta, S.M. (2004). Money, banking \& finance: Theory and practice. Owerri: Hudson-Jude Nigeria Publishers.

Okello, P. A., \& Muturi, W. (2018). Influence of non-interest income on financial performance of commercial banks listed at the Nairobi securities exchange. International Journal of Social Sciences and Information Technology, 4(5), 532-549.

Okibo, B. W., \& Wario, A. Y. (2014). Effects of e-banking on growth of customer base in Kenyan banks. International Journal of Research in Management \& Business Studies, 1(1), 78-84.

Olokoyo, F. O. (2011). Determinants of commercial banks' lending behavior in Nigeria. International Journal of Financial Research, 2(2), 61-72. doi:10.5430/ijfr.v2n2p61

Oniang'o, R. (2015). Effect of non-interest income on profitability of commercial banks in Kenya. A research project submitted in partial fulfillment of the requirements for the award of the degree of Master of Science finance, school of business. University of Nairobi.

Onwudiwe, C. C. (2017). Legal aspects of electronic banking in Nigeria: An overview. A key note paper presented at CBN annual lectures. Managing Partner Harvard Law Firm.

Panigrahi, S. (2017). Economic value added and traditional accounting measures for shareholder's wealth creation. Asian Journal of Accounting and Governance, 8, 125-136. doi:10.17576/AJAG-2017-08-11

Penrose, E. T. (1959). The theory of the growth of the firm. Wiley.

Ritter, S., \& Udel, M. F. (1996). Money Banking and Financial Markets (11th ed.).

Ross, S. A., Westerfield, R., \& Jaffe, J. (2002). Capital market theory: An overview. Corporate finance (6th ed.). McGraw-Hill. 
Saunders, A., \& Walter, I. (2005). Universal Banking in the United States: What could we gain? what could we lose? Oxford University Press.

Senyo, D. B., Olivia, A. T., \& Musah, A. (2015). Income diversification and financial stability of banks in Ghana. International Journal of Business and Social Science, 6, 6.

Shaikh, A. A., \& Karjaluoto, H. (2015). Mobile banking adoption: A literature review. Telematics and Informatics, 32(1), 129-142. doi:10.1016/j.tele.2014.05.003

Stewart, G. B. (1991). The quest for value: The EVA Management Guide. Harper Business.

Sun, L., Wu, S., Zhu, Z., \& Stephenson, A. (2017). Noninterest income and performance of commercial banking in China. Journal of Scientiðc Programming, 1-8.

Veneeya, V. (2006). Analysis of modern portfolio theory. Coursework4you. Retrieved on 15/11/18fromhttp:// www.articlesbase.com/finance-articles/analysis-of-modern-portfolio- theory 40421.htm

Wibowo, P. P., \& Berasategui, R. G. (2008). The relationship between economic value added (EVA) and market value added (MVA) with reported earnings: An empirical research of 40 listed companies in Indonesia stock exchange for the year 2004-2007. Journal of Applied Finance and Accounting, 1(1), 60-72.

Williams, B. (2016). The impact of non-interest income on bank risk in Australia. Journal of Banking \& Finance, 73, 16-37. doi:10.1016/j.jbankfin.2016.07.019

Williamson, O. E. (1967). Hierarchical control and optimum firm size. Journal of Political Economy, 75(2), 123-138. doi:10.1086/259258

Worku, G. (2010). Electronic-banking in Ethiopia-practices, opportunities and challenges. Journal of Internet Banking and Commerce, 15(2), 10-51.

Yee-Loong, C. A., Ooi, K. B., Lin, B., \& Tan, B. I. (2010). Online banking adoption: An empirical analysis. International Journal of Bank Marketing, 28(4), 267-287. doi:10.1108/02652321011054963

Young, S. D., \& O’Byrne, S. F. (2000). EVA and Value-Based Management: A practical guide to implementation. McGraw-Hill Inc.

Zeitun, R., \& Tian, G. G. (2007). Capital structure and corporate performance. Evidence from Jordan. Australian Accounting Business and Finance Journal, 1(4), 104-115. doi:10.14453/aabfj.v1i4.3

Emmanuel Uniamikogbo is a Senior Lecturer in the Department of Accounting, College of Management and Social Sciences at Rhema University, Nigeria, Aba. He is currently conducting a Doctoral research in Accounting from Nnamdi Azikiwe University, Awka, Nigeria. His primary research interest is in taxation with special focus on personal income tax. He also researches into other areas such as Corporate Finance, Public Sector Accounting, Corporate Governance, Accounting Education, Auditing, International Accounting and Oil \& Gas accounting. He has presented scholarly papers at international and local conferences. He is an associate of the Institute of Strategic Management of Nigeria (ISMN) and a student member of the Institute of Chartered Accountants of Nigeria (ICAN). He is a seasoned researcher, motivational speaker and public policy analyst. 